\title{
ANALISIS KESALAHAN PENGUCAPAN PADA PROGRAM TALK SHOW DI TELEVISI INDONESIA
}

Error Analysis Spelling Talkshow Program In Television Indonesia

\author{
Emmy Erwina \\ Universitas Harapan Medan, Medan, Indonesia \\ emmyerwina8@gmail.com
}

Naskah Diterima Tanggal 4 Maret 2020_Direvisi Akhir Tanggal 24 Oktober 2020_Disetujui Tanggal 20 November 2020 doi: https://doi.org/10.26499/rnh.v9i2.2849

\begin{abstract}
Abstrak
Penelitian ini membahas tentang analisis kesalahan pengucapan pada talkshow yang terjadi di beberapa stasiun televisi di Indonesia. Data yang dianalisis merupakan data yang digunakan untuk mengetahui apakah bahasa lisan standar digunakan dalam acara bincang-bincang atau tidak dan apakah kesalahan yang ditemukan dalam acara bincang-bincang dipengaruhi oleh bahasa standar yang digunakan. Penelitian ini merupakan studi fonetik tentang bunyi dan pengucapan bahasa Indonesia. Kerangka teori yang digunakan dalam penelitian ini didasarkan pada teori analisis kesalahan seperti Corder, Selinker, dan Richards. Hal ini juga didasarkan pada teori-teori linguistik struktural seperti yang dielaborasi oleh Pike dan yang dikemukakan oleh Kridalaksana dalam menganalisis kesalahan bunyi bahasa Indonesia. Rancangan metode penelitian yang digunakan dalam penelitian ini sesuai dengan analisis kesalahan dalam menganalisis data kesalahan yang dikumpulkan dari survei penonton talk show di setiap stasiun televisi di Indonesia. Penelitian dilakukan untuk menganalisis kesalahan bunyi vokal, diftong, dan konsonan. Temuan penelitian ini menunjukkan bahwa kesalahan yang ditemukan pada data adalah sebagai berikut: kesalahan antarbahasa seperti hypercorrection untuk menghindari penggunaan bahasa standar yang disebabkan oleh bahasa ibu seperti bahasa Jawa, Batak, dan bahasa gaul.

Kata-kata Kunci: fonetik, pengucapan, analisis kesalahan
\end{abstract}

\begin{abstract}
This study discusses the analysis of pronunciation errors in talk shows that occur in several television stations in Indonesia. The data collected for analysis was to see whether the standard spoken language used in talk shows or not when Speaking in talk shows and the errors found in their talk shows were constructed by their language standards. This research is a phonetic study of Indonesian sounds and pronunciation only. The theoretical framework used in this study is based on error analysis theory such as Corder, Selinker and Richards. It is also based on structural linguistic theories such as those elaborated by Pike and those put forward by Kridalaksana in analyzing sound errors in Indonesian. The design of the research method used in this study is in accordance with the error analysis in analyzing the error data collected from the talk show audience survey at each television station in Indonesia. This research was conducted to analyze the errors of vowels, diphtongs, and consonants. This investigation shows that the errors found in the data are as follows: inter-language errors such as hypercorrection to take advantage of the use of standard languages caused by mother tongues such as Javanese, Batak, and Slang.
\end{abstract}

Keywords: phonetics, pronunciation, error analysis

How to Cite: Erwina, Emmy. (2020). Analisis Kesalahan Pengucapan Pada Program Talk Show Di Televisi Indonesia. Ranah: Jurnal Kajian Bahasa. 9(2). 178-187. doi: https://doi.org/10.26499/rnh.v9i2.2849 


\section{PENDAHULUAN}

Masalah pengucapan merupakan masalah bahasa yang penting dalam perkembangan bahasa Indonesia. Permasalahan bahasa yang perlu mendapat perhatian dalam perkembangan bahasa Indonesia adalah masalah sebutan atau lafal, namun banyak masyarakat yang masih belum berani mempelajarinya secara mendalam karena bangsa Indonesia terdiri dari berbagai suku bangsa yang masing-masing memiliki bahasa daerahnya sendiri. Pengaruh bahasa asing, bahasa daerah atau dialek terhadap bahasa Indonesia terlihat pada beberapa acara bincangbincang di setiap stasiun televisi di Indonesia, karena sifatnya yang audiovisual, televisi dapat menghadirkan acara musik, film, sinetron, variety show, reality show, serta acara lainnya dengan melibatkan para selebritis idola khalayak (Abdullah Aceng \& Lilis Puspitasari, 2018: 102). Selain itu juga dipengaruhi oleh beberapa bahasa asing seperti Belanda, Inggris, Arab, dan Sansekerta. Pengaruh bahasa asing, bahasa daerah atau dialek terhadap bahasa Indonesia dapat dilihat pada banyak lafaz atau sebutan. Pengaruh ini menyebabkan kurangnya keseragaman dalam penunjukan. Hal inilah yang mungkin menjadi penyebab hingga saat ini di Indonesia belum ada pedoman penunjukan standar untuk bahasa Indonesia. Hal ini mungkin juga berlaku karena Indonesia terdiri dari wilayah yang sangat luas dan memiliki ragam bahasa, sehingga sangat sulit untuk membakukan sebutan bahasa Indonesia atau memilih salah satu istilah bahasa daerah yang dapat dijadikan acuan standar bahasa Indonesia. Dengan kata lain, bahwa secara resmi tidak ada sebutan baku untuk bahasa Indonesia. Ketidakseragaman sebutan ini membingungkan masyarakat umum, misalnya para pemain talk show di beberapa stasiun televisi, pemirsa televisi, dan pendengar radio dalam membedakan antara bentuk standar dan nonstandar. Sebutan non-seragam Indonesia sering kali diterapkan dalam situasi formal. Situasi formal berarti situasi yang terjadi di tempat umum (masyarakat umum), tidak tertutup, memiliki peraturan perundang-undangan dan mengikuti adat istiadat yang berlaku (Kamus Besar Bahasa Indonesia, 2008: 279—837).

Bahasa Indonesia yang baik adalah bahasa yang digunakan sesuai situasi dan kondisi, sedangkan bahasa Indonesia yang benar adalah yang sesuai dengan EYD (Setiawati, Selis, 2016: 45). Sebutan baku bahasa Indonesia ialah sebutan yang mengikut prinsip fonemik yang berdasarkan ejaan bahasa Indonesia, maksudnya sesuatu perkataan dilafazkan mengikut ejaan baku bahasa Indonesia atau menurut nilai bunyi huruf di dalam bahasa Indonesia. Ragam baku adalah ragam yang dilembagakan dan diakui oleh sebagian besar warga masyarakat pemakainya sebagai bahasa resmi dan sebagai kerangka rujukan norma bahasa dalam pengunaannya (Jamilah, 2017: 42). Hal ini dapat dilihat dalam contoh kata makan yang 
diucapkan sebagai [mãkan] dan kata masalah yang diucapkan sebagai [mãsalah]. Bunyi yang digambarkan dengan huruf $a$ haruslah diucapkan sebagai [a] dan jangan berubah menjadi [e], [ə], atau [ع]. Kemudian, bunyi [k] yang terdapat di tengah kata haruslah diucapkan secara jelas dan jangan diganti dengan bunyi glotis [?], contohnya perkataan 'pendidikan' jangan diucapkan sebagai [pəndidi?kan] tetapi harus diucapkan sebagai [pəndidikan], dan perkataan 'kedudukan' jangan diucapkan sebagai [kedudu?kan] tetapi harus diucapkan sebagai [kədudukan], manakala perkataan seperti 'mendudukkan' haruslah diucapkan sebagai [mənduduPkan], dan perkataan 'meletakkan' haruslah disebut sebagai [mələta?kan] jadi, 'k' yang pertama diucapkan dengan bunyi glotis [?] dan ' $\mathrm{k}$ ' yang kedua diucapkan secara jelas (Prihadi, $2010: 60$ ).

Oleh karena itu, penulisan karya-karya ilmiah, baik berupa buku-buku teks pelajaran, buku-buku ilmiah maupun karya tulis ilmiah lainnya menggunakan ragam baku tulis sebagai standar penulisannya (Jamilah, 2017: 42), misalnya, jika seseorang itu berasal dari suku Jawa, maka sebutan perkataan mereka dipengaruhi oleh bahasa Jawa, jika suku Batak dipengaruhi oleh bahasa Batak, suku Sunda dipengaruhi oleh bahasa Sunda, dan orang Jakarta dipengaruhi oleh dialek Betawi.

Penelitian ini membahas tentang analisis dan perbandingan pengucapan yang berbeda pada ucapan yang dihasilkan oleh pembawa acara dan bintang tamu yang berdiskusi di stasiun televisi di Indonesia dalam situasi yang formal. Hal ini bertujuan untuk mengetahui penyebab dari perbedaan pengucapan. Signifikasi penelitian ini ialah untuk menjelaskan bagaimana petunjuk pelafalan yang benar serta untuk memberikan kontribusi kepada para praktisi agar dapat mengimplementasikannya pada pengucapan yang sudah sesuai dengan standar.

\section{LANDASAN TEORI}

Penulis mendapati bahwa teori struktural sesuai dengan kajian yang dilakukan oleh penulis, yaitu mengenai kajian sebutan kata baku bahasa Indonesia. Pendekatan struktural ialah langkah-langkah tertentu dalam melakukan penelitian. Dalam penelitian bahasa, kita harus melakukan penelitian fonologi terlebih dahulu sebelum melakukan penelitian morfologi dan penelitian sintaksis. Penelitian fonologi akan menjadi landasan untuk penelitian morfologi dan penelitian morfologi akan menjadi landasan untuk penelitian sintaksis (Ismawati, 2011: 38). Pendekatan struktural berfokus pada pencarian bentuk (form) dari gejala yang ada. Berdasarkan gejala itu, disusunlah suatu sistem yang dapat menjelaskan keberadaan bentuk tersebut. Dalam penelitian bahasa, bentuk itu dapat berupa sistem bunyi bahasa (fonetik), 
fonem, morfem, kata, frasa, klausa, dan kalimat (Setiawan, 2016). Uraian deskriptif yang diterapkan oleh pengkaji untuk analisis kajian ini ialah aliran struktural Amerika. Aliran ini mewarisi ide dari para ahli antropologi budaya seperti Boas, ahli bahasa Bloomfield, serta ahli bahasa dan antropologi budaya. Teori yang juga digunakan dalam penelitian ini, yaitu kutipan wawasannya: "One of the significant units of sounds arrived at for a particular language by the analytical... a constrastive sound unit". Oleh karena itu, dapat dikatakan fonem sebagai satuan terkecil dapat diwujudkan dalam satuan kontras, yaitu pasangan minimal, misalnya, [čari] mencari dan [jari] jari tangan atau kaki. Dengan melakukan segmentasi pasangan minimal dan struktur fonemik dalam tuturan para informan dengan menggunakan analisis kesalahan-kesalahan atau perbedaan pengucapan dapat dipertanggungjawabkan, jika tidak maka akan terjadi perubahan dan pergeseran makna dari kata tersebut. Perubahan makna tersebut merupakan makna yang sebenarnya mengalami perubahan, sedangkan untuk pergeseran makna merupakan gejala penyempitan, perluasan, pengonotasian, dan pengasosiasian makna apakah makna tersebut masih layak di dalam satu medan makna (S. Ramadan \& Y. Mulyati, 2020: 4). Terdapat berbagai kecenderungan yang kuat bahwa penggunaan Bahasa Indonesia mengalami pergeseran yang disebabkan oleh Bahasa Asing, seperti di media televisi, koran, baliho, iklan dan lain-lain. Kepedulian pengguna bahasa Indonesia sangat ada kaitannya dengan kualitas pengguna bahasa Indonesia tersebut ( $R$. Rahayu, 2017: 32).

Kualitas berbahasa seseorang dilihat dari kuantitas kosakata yang dikuasainya. Semakin banyak kosakata yang dikuasainya, maka kualitas berbahasanya pun semakin baik (F.A.D., H. Astuti, N. Sukmawati, 2019: 127). Namun, semakin banyak kosakata yang dimiliki seseorang, kesalahan berbahasanya pun tetap tak mungkin dihindari. Kesalahan berbahasa ialah penyimpangan dari kaidah-kaidah berbahasa, baik dari segi lisan maupun tulisan. Jadi, analisis kesalahan berbahasa ialah analisis tentang penyimpangan berbahasa yang terjadi di dalam proses mempelajari bahasa.

Akan tetapi, kesalahan berbahasa mesti dibedakan dengan kekeliruan, sehingga dapat diketahui bahwa kekeliruan ialah berbahasa yang tidak sistematis yang mengacu kepada gagalnya penampilan (performance), sedangkan kesalahan ialah penyimpangan yang sistematis yang berhubungan dengan gagalnya kemampuan atau kompeten (competence) (Azmi, 2011: 42). Kesalahan itu dapat dibedakan kepada dua, yaitu kesalahan antarbahasa (interlanguage errors) dan kesalahan intrabahasa (intralingual errors). Penyebab kesalahan intrabahasa itu dapat dibagi menjadi 1) pengitlakan (over-generalizations), 2) tidak mengetahui pembatasan 
rumus (ignorance of rule restrictions), 3) penerapan rumus yang kurang sempurna(incomplete application of rules), dan 4) membuat kesimpulan yang salah mengenai konsep (false concepts hypothesized).

\section{METODE PENELITIAN}

Data yang digunakan dalam penelitian ini merupakan survei yang diisi oleh beberapa orang terkait dengan kesalahan pengucapan kata yang dilakukan informan (pembawa acara, narasumber, dan panitia) pada acara talk show di stasiun televisi di Indonesia. Metode pemilihan data dilihat berdasarkan jenis stasiun televisi yang dipilih, tingkat pengetahuan terhadap acara televisi yang dipilih, acara talk show yang pernah dilihat/ ditonton, serta pengaruh kesalahan pengucapan kata yang dilakukan informan yang mengakibatkan acara talk show sering berulang.

Menurut Solimun (2017: 21), arti penting pencatatan adalah agar data dapat dianalisis berulang kali sehingga mendapatkan data yang valid. Untuk melakukan penelitian ini, peneliti menyebar kuisioner yang berbentuk survei kepada masyarakat dengan menggunakan google form. Peneliti kemudian mengambil data dengan method average (metode rata-rata) dari hasil survei tersebut. Peneliti dapat menghitung berapa tingkat error dalam pengucapan kata di acara talk show di beberapa stasiun televisi di Indonesia. Penelitian ini sangat dibutuhkan bukan hanya untuk mengukur pengucapan (speeling) dalam acara talk show, tetapi juga dapat memperbaiki pengucapan (speeling) dari acara talk show yang ada di Indonesia. Tanpa menggunakan survei dan method average (metode rata-rata), sulit untuk memastikan apakah data tersebut sudah benar dan lengkap.

\section{PEMBAHASAN}

Survei diisi oleh 90 responden, dengan rincian usia sebagai berikut, 73,3\% berusia lebih dari 20 tahun, 17,8\% berusia kurang dari 20 tahun, dan 8,9\% berusia 20 tahun. Hal ini berarti minat responden untuk melihat dan menganalisis kesalahan pengucapan (error spelling) pada acara talk show di beberapa stasiun televisi rata-rata berasal dari usia lebih dari 20 tahun.

Berdasarkan data survei terkait dengan penelitian ini menunjukkan bahwa sebanyak $51,1 \%$ responden berjenis kelamin laki-laki dan $48,9 \%$ berjenis kelamin perempuan. Hal ini menunjukkan bahwa persentase responden yang berjenis kelamin laki-laki lebih tinggi dibandingkan dengan responden yang berjenis kelamin perempuan dalam melihat dan 
menganalisis kesalahan pengucapan (error spelling) kata pada acara talk show di beberapa stasiun televisi.

Provinsi

90 tanggapan
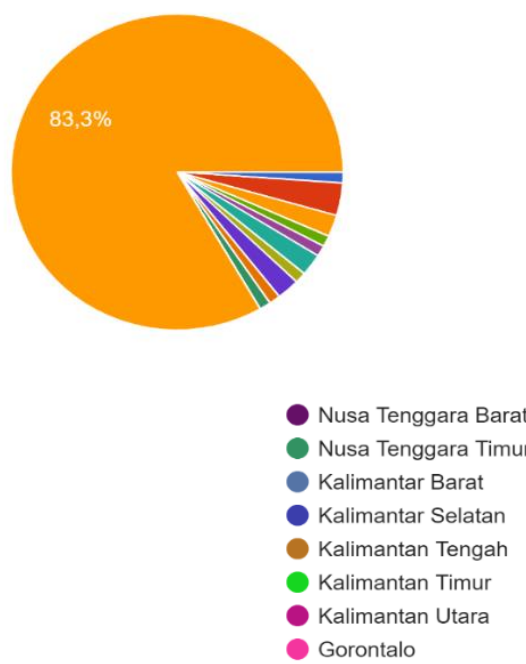

$\boldsymbol{\Delta} 3 / 5 \boldsymbol{\nabla}$

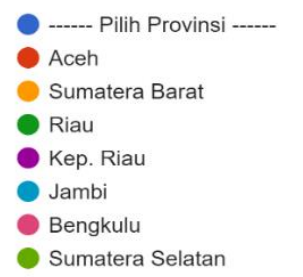

Sumatera Selatan

$\Delta 1 / 5 \nabla$

Sulawesi Selatan

Sulawesi Tenggara

- Sulawesi Tengah

- Sulawesi Utara

Sulawesi Barat

Maluku

Maluku Utara

Papua

A $4 / 5 \boldsymbol{V}$
Kep. Bangka Belitung

Lampung

Banten

DKI Jakarta

Jawa Tengah

- Jawa Timur

DI Yogyakarta

Bali

$\boldsymbol{\Delta}^{2 / 5} \boldsymbol{\nabla}$

Papua Barat

- Sumatera Utara

A $5 / 5 \nabla$

Berdasarkan diagram survei di atas, di antara 90 responden yang mengisi survei semua berasal dari 11 provinsi dari 34 provinsi yang ada di Indonesia. Persentase tertinggi atas responden yang mengisi survei berasal dari provinsi Sumatra Utara, yaitu sekitar 84,1\%. Sisanya memiliki presentasi $<5 \%$. Hal ini menunjukkan bahwa minat responden untuk menonton dan menganalisis kesalahan pengucapan (error spelling) pada acara talkshow di beberapa stasiun televisi masih didominasi responden yang berasal dari provinsi Sumatera Utara.

Stasiun TV di indonesia :

90 tanggapan
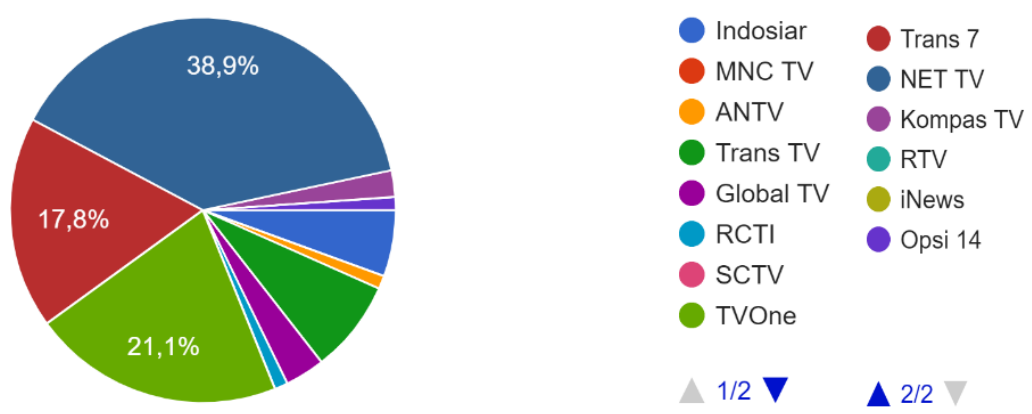

Berdasarkan diagram survei di atas dapat diketahui bahwa terdapat 14 stasiun televisi di 
Indonesia, tetapi hanya 10 stasiun televisi yang dipilih oleh 90 responden. Berdasarkan 10 stasiun televisi tersebut, stasiun televisi NET TV mendapatkan presentasi paling tinggi yaitu sebesar 38,9 \%. Persentase paling tinggi kedua yaitu stasiun televisi TV One dengan persentase $21,1 \%$. Persentase paling tinggi ketiga yaitu stasiun televisi Trans 7 dengan presentasi $17,8 \%$. Persentase paling tinggi keempat yaitu stasiun televisi Trans TV dengan presentasi 7,8\%. Persentase paling tinggi kelima yaitu stasiun televisi Indosiar dengan persentase 5,6\%. Untuk presentase paling rendah yaitu stasiun televisi ANTV dan RCTI dengan persentase $1,1 \%$. Hal ini menunjukkan bahwa responden paling banyak memilih stasiun televisi NET TV.

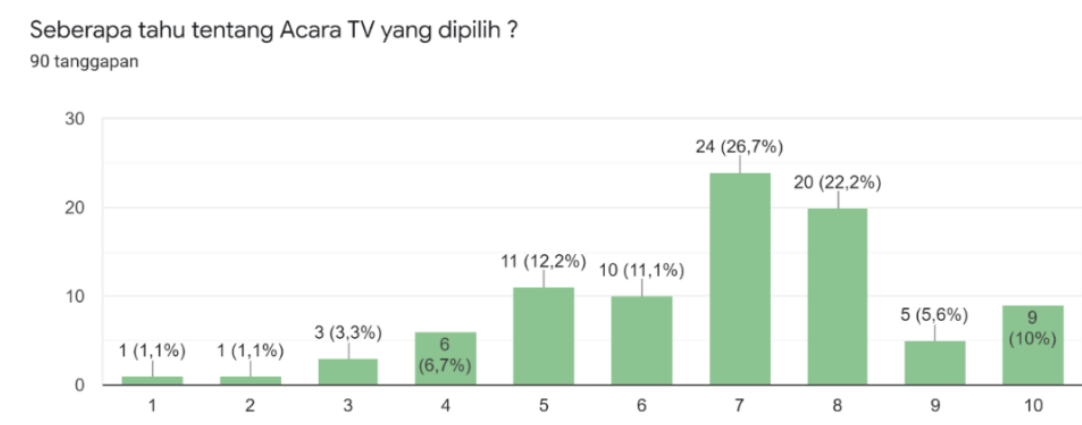

Berdasarkan diagram survei di atas, diketahui terdapat 10 tingkat pengetahuan responden terhadap stasiun televisi yang dipilih. Diketahui bahwa dari 90 responden, skala 7 merupakan skala yang paling banyak dipilih oleh responden terkait dengan pengetahuan acara televisi, dengan persentase 26,7\%. Skala tertinggi kedua, yaitu skala 8 dengan persentase 22,2\%. Skala tertinggi ketiga, yaitu skala 5 dengan persentase 12,2\%. Terdapat 6 tingkat skala dengan persentase tidak lebih dari $12 \%$. Hal ini menunjukkan bahwa tingkat pengetahuan responden terhadap acara talk show pada stasiun televisi berada pada skala 7 .

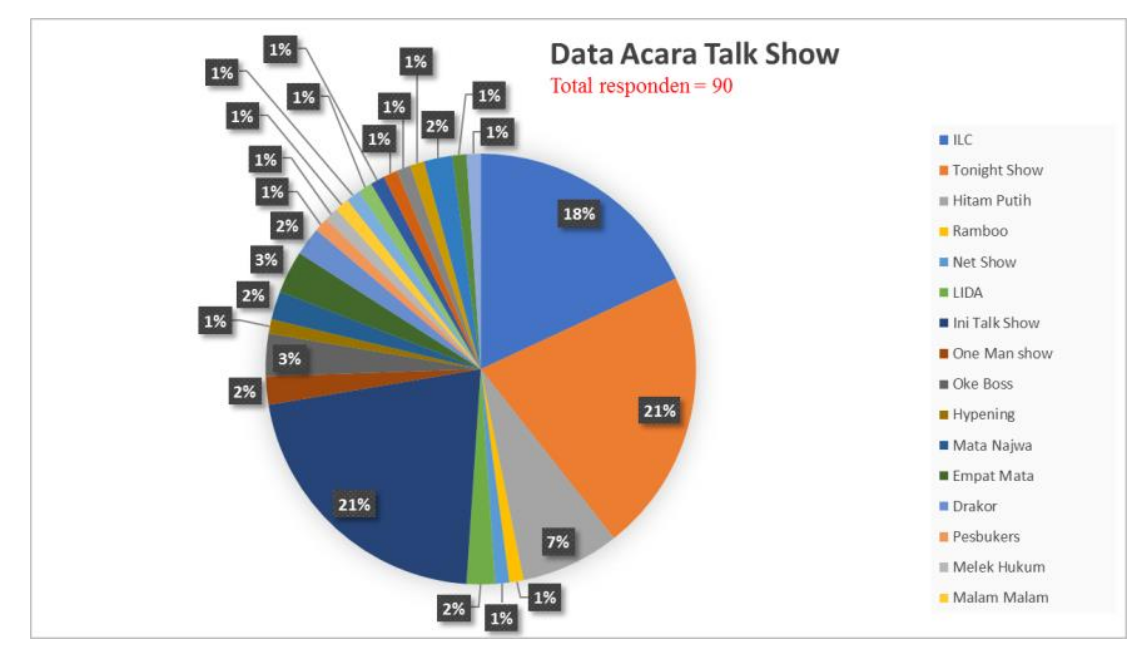


Berdasarkan data di atas, acara talk show Tonight Show dan Ini Talk Show memiliki tingkat persentase yang sama dan tertinggi, yaitu sebesar 21\%. Acara talk show dengan tingkat persentase tertinggi kedua yaitu ILC, sebesar 18\%. Acara talk show dengan tingkat persentase tertinggi ketiga yaitu Hitam Putih, sebesar 7\%. Terdapat 14 acara talk show dengan tingkat persentase paling rendah, yaitu berkisar antara 3-1\%. Hal ini menunjukkan bahwa responden lebih banyak menonton dan menganalisis kesalahan pengucapan (Error Spelling) pada acara talk show Tonight Show dan Ini Talk Show berdasarkan stasiun televisi yang dipilih oleh responden.

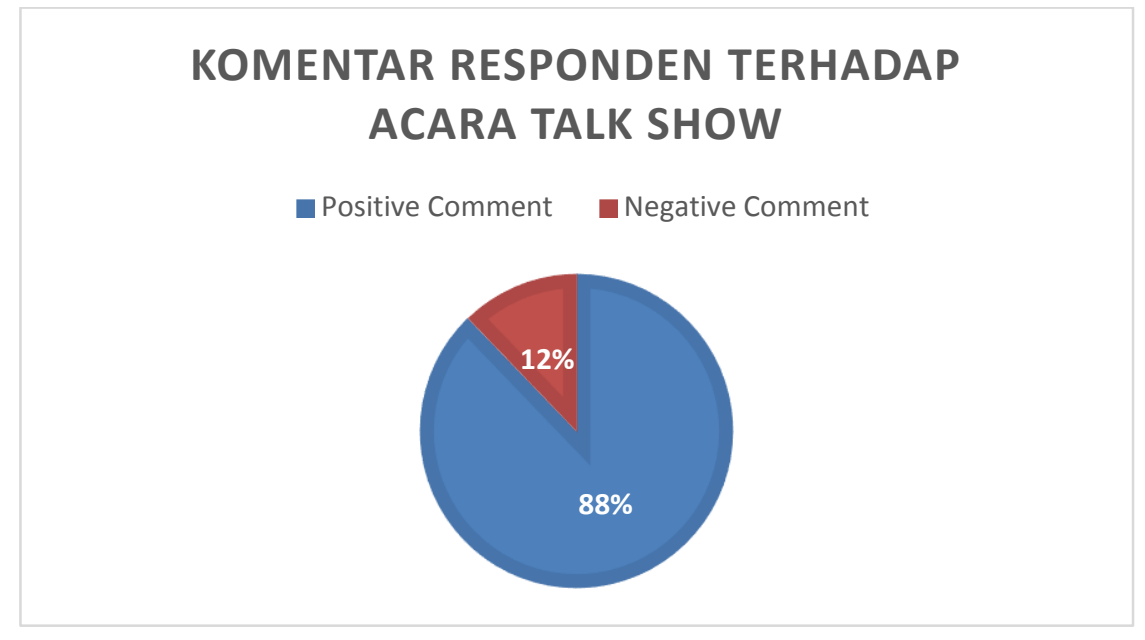

Berdasarkan diagram survei di atas, dapat diketahui komentar responden terhadap acara talk show yang ditonton. Komentar tersebut terbagi menjadi dua bagian, yaitu komentar positif dan negatif. Berdasarkan diagram survei di atas, komentar positif yang diberikan oleh para responden memiliki persentase tinggi sebesar $88 \%$. Sisanya, sebesar $12 \%$ komentar yang diberikan oleh para responden mengandung komentar yang negatif. Hal ini menunjukkan bahwa komentar negatif yang diberikan oleh para responden memiliki hubungan dengan kesalahan pengucapan (Error Spelling) pada acara talk show di stasiun televisi. Komentar negatif tersebut mengandung unsur yang berulang pada setiap acara talk show. Unsur berulang tersebut membuat para responden merasa bosan untuk menonton dan melihat acara talk show di stasiun televisi.

\section{PENUTUP}

Berdasarkan analisis data yang telah didapatkan di atas, dari 100 orang yang didata untuk mengisi survei penelitian ini, sebanyak 90 orang dengan persentase $90 \%$ ikut berpartisipasi dalam pengisian survei penelitian ini. Sisanya, sebanyak 10 orang dengan 
persentase $10 \%$ tidak berpartisipasi dalam pengisian survei (error survey). Berdasarkan data 90 responden, sebesar 38,9\% memilih stasiun televisi NET TV sebagai stasiun televisi yang memiliki acara talk show paling banyak ditonton. Hal ini menunjukkan bahwa stasiun televisi NET TV memiliki program acara talk show yang menggunakan bahasa gaul/ bahasa pasar/ bahasa tidak baku dalam pengucapan kata di setiap program acara talk show yang ditayangkan. Sehingga terjadi kesamaan kesalahan pengucapan (error spelling) yang menyebabkan acara talk show tersebut menjadi berulang ditayangkan.

Komentar yang diberikan oleh para responden terdiri atas dua jenis komentar, yaitu komentar positif dan komentar negatif. Berdasarkan data, komentar positif masih memiliki persentase tinggi sebesar $88 \%$ dari total jumlah responden. Dapat disimpulkan, para penonton yang menonton acara talk show di beberapa stasiun televisi tidak mementingkan kesalahan pengucapan (error spelling), tetapi lebih mementingkan tema dari konten acara talk show yang ditayangkan. Hal ini membuktikan bahwa penggunaan bahasa baku yang sesuai berdasarkan Kamus Besar Bahasa Indonesia (KBBI) tahun 2008 tidak terlalu dipentingkan dalam acara talk show di stasiun televisi.

\section{DAFTAR PUSTAKA}

A.D., Firman, Heksa Biopsi Puji Hastuti, NFN Sukmawati, and NFN Rahmawati. (2019). Analisis Hubungan Penguasaan Kosakata dan Kemampuan Memahami Unsur Intrinsik Cerpen Siswa SMP Di Kota Kendari. Ranah: Jurnal Kajian Bahasa. 8(1). https://doi.org/10.26499/rnh.v8i1.636

Abdullah, Aceng, and Lilis Puspitasari. (2018). Media Televisi di Era Internet. ProTVF. 2(1). https://doi.org/10.24198/ptvf.v2i1.19880

Azmi, Ahmad Sanusi. (2011). Kekeliruan dan Kritikan Terhadap Sahih Bukhari: Satu Tinjauan Awal. Jurnal Hadis. Vol. 1.

Faisal, Abdul Jalil. (2008). Penggunaan Bahasa Indonesia Baku dalam Tesis Mahasiswa S-2. Linguistik Indonesia. Vol. 2.

Ismawati, N, and N Hindarto. (2011). Pendekatan Struktural Two Stay Two Stray Untuk Meningkatkan Hasil Belajar Siswa Kelas X Sma. Pendidikan Fisika Indonesia. Volume 7.

Jamilah, Jamilah. (2017). Penggunaan Bahasa Baku dalam Karya Ilmiah Mahasiswa. Jurnal Tarbiyah: Jurnal Ilmiah Kependidikan. 6(2). https://doi.org/10.18592/tarbiyah.v6i2.1603

Nugroho, Rahadian Duwi, Cicilia Tantri Suryawati, and Hendri Zuliastutik. (2019). Analisis Kesalahan dalam Penulisan Karya Ilmiah Mahasiswa Jepang dalam Pembelajaran BIPA. Jurnal Pendidikan Bahasa dan Sastra. 18(2). https://doi.org/10.17509/bs ipbsp.v18i2.15508

Prihadi. (2010). Media Pembelajaran Bahasa Indonesia. Jakarta: Direktorat Jendral Pendidikan Lanjutan Pertama Kemendiknas.

Rahayu, Ratih. (2017). Pengaruh Pengetahuan Tentang Peraturan Kebahasaan terhadap Sikap Bahasa Pengusaha Kuliner di Kabupaten Pringsewu. Ranah: Jurnal Kajian Bahasa. 6(1). https://doi.org/10.26499/rnh.v6i1.260

Ramadan, Syahru, and Yeti Mulyati. (2020). Makna Kata dalam Bahasa Indonesia (Salah Kaprah dan Upaya Perbaikannya). Ranah: Jurnal Kajian Bahasa. 9(1). https://doi.org/10.31227/osf.io/s3dkw

Setiawan, Dwi Agus. (2016). Analisis Kesalahan Sintaksis Bahasa Indonesia dalam Karangan 
Deskripsi Siswa Kelas VI SDN Kanigoro 02 Kecamatan Pagelaran yang Berbahasa Ibu Bahasa Madura. Pancaran. 5(3).

Solimun, Adji Achmad Rinaldo Fernandes, and Nurjannah. (2017). Metode Statistika Multivariat Pemodelan Persamaan Struktural (SEM) Pendekatan WarpPLS. In Metode Statistika Multivariat Pemodelan Persamaan Struktural (SEM) Pendekatan WarpPLS. 